\title{
トマト細菌性病害に対する次亜塩素酸カルシウム製剂の 二次伝染抑止効果
}

\author{
渡辺秀樹・村元靖典・棚橋寿彦・中保一浩* \\ (岐皁県農業技術センター・*農研機構野菜花き研究部門)
}

\begin{abstract}
Control of secondary infections of tomato bacterial disease using calcium hypochlorite was evaluated. Effective concentrations of calcium hypochlorite differed between bacterial wilt and canker. In particular, even at $0.2 \%$, calcium hypochlorite could not completely suppress bacterial canker. Furthermore, at concentrations of less than $0.2 \%$, the control effect declined sharply. Alternatively, because concentrations of residual chlorine in calcium hypochlorite solutions decrease in light conditions, the control effects may deteriorate markedly depending on management.
\end{abstract}

Key words: bacterial wilt, bacterial canker, calcium hypochlorite

トマト栽培において, 青枯病（病原菌: Ralstonia solanacearum), かいよう病菌（病原菌：Clavibacter michiganensis subsp. michiganensis) などの細菌性病害は, 土袞伝染だけでなくハサミ等を介して地上部からも容易 に伝染する。漆原ら（2002）および川口ら（2011）は， 次亜塩素酸カルシウム製剂の500倍液によるハサミや手 袋の消毒がトマトかいよう病菌の二次伝染対策に有効で あると報告しており，現地においても同剤が多く使用さ れている。一方で, 塩素系消毒剤は, 陽光条件下で有効 塩素濃度が低下することが知られているものの，農業現 場においては具体的な情報が少ない。そこで，青枯病や かいよう病に対する塩素系消毒剤の希釈有効倍率および 圃場条件下における塩素濃度の変化について検討した。

\section{試験 1}

\section{材料および方法}

トマト青枯病菌とかいよう病菌に対する塩素系消毒剂 の有効希釈倍率を評価するため，2015年10月20日～11月 19日にガラス温室内で試験を行った。青枯病菌およびか いよう病菌は, それぞれ当センター保有の GF1445 およ び GF1449 菌株を供試し，ジャガイモショ糖液体培地で 4 日間振とう培養して得られた菌懸濁液（約 $10^{8} \mathrm{cfu} / \mathrm{ml}$ )
を接種源として用いた。園芸用はさみの刃先に約 $2 \mathrm{ml}$ の菌懸濁液を噴霧し, 直ちに次亜塩素酸カルシウム製剤 （日本曹達：ケミクロン G）の希勫液約 $4 \mathrm{ml}$ をハサミの 両面に噴霧して, 第 4 本葉展開期のトマト苗（品種: 桃 太郎 8 ）の第 1 本葉を切除した。希橎倍率は，2 倍希釈 系列で500倍〜 512,000倍まで11段階に設定した。対照区 は次亜塩素酸カルシウムの代わりに滅菌水を同様に噴霧 した。各区 8 株を供試し, 同様の手順を繰り返した。各 区の発病株数を，5 日間隔で30日後まで調査した。

\section{試験 2}

かいよう病菌を対象に, 次亜塩素酸カルシウム製剂を 10倍～8,000倍まで 7 段階に希釈し，2016年 1 月13日〜 2 月 17 日に前述と同様の手順で試験を行った。各区12株 を供試し, 発病株数を概ね 5 日間隔で35日後まで調べた。 試験 3

塩素系消毒剤の保管状態が有効塩素濃度に及ぼす影響 を把握するため, 以下の試験を2015年11月に行った。次 亜塩素酸カルシウム製剂の500倍希釈液 $250 \mathrm{ml}$ を透明ポ リプロピレン容器に充填したもの（光遮蔽なし）と, 同 容器に充填後アルミ䇴で容器を被覆したもの（光遮蔽あ り）を供試した。これらをビニールハウス, 室内の直射 日光が当たらない棚の上, および $5{ }^{\circ} \mathrm{C}$ に設定した冷蔵庫 内に配置し，0，1，3，5，7 日後に試料を回収し，（株） 共立理化学研究所の水質測定試薬セット LR-CLO-C（よ う化カリウム法キット）を用いて残留塩素濃度を測定し た。各区 2 反復とした。各設置場所の気温と照度は, デー タロガー（T \& D : おんどとり TR-74Ui）で収集した。

\section{結果および考察}

試験 1 において, 対照区の青枯病およびかいよう病の 発生は,いずれも処理 8 日後から確認された。青枯病は, 次亜塩素酸カルシウム製剂の 2000 倍以下の希勫濃度で処 理30日後に発病が全く認められなかったのに対して，か

Hideki Watanabe, Yasunori Muramoto, Toshihiko Tanahashi and Kazuhiro Nakaho* (Gifu Pref. Agr. Tech. Ctr., *NARO Veg. \& Flor. Sci.): Secondary infection control of bacterial tomato disease using calcium hypochlorite 2019年 2 月20日受理

責任著者 : 渡辺秀樹・watanabe-hideki@pref.gifu.lg.jp 
いよう病は500倍希釈で $25 \%$ の株が発病し，青枯病菌と かいよう病菌に対する次亜塩素酸カルシウム製剂の希釈 有効倍率に差が認められた（第 1 表）。このことから， かいよう病菌は青枯病菌と比較して, より高濃度の有効 塩素濃度が必要であることが示唆された。かいよう病菌 はグラム陽性菌であり，グラム陰性菌である青枯病菌と 細胞壁構造が大きく異なる。このことが本試験の結果と 関係している可能性が考えられるが，この点については さらに検討が必要である。次に, 試験 2 において，かい よう病を対象に次亜塩素酸カルシウム製剂の希釈倍率を 下げ，より高濃度条件で二次伝染抑制効果を検討した。 その結果，1,000倍以上の希釈倍率では発病が認められ たが, 500倍以下では発病が認められなかった（第 2 表）。 漆原ら（2002）は，次亜塩素酸カルシウム製剤の500倍 および1,000倍液を八サミに噴霧することで，かいよう 病の発病を，0\%抢よび $14.3 \%$ に抑制できたと報告して おり, 試験 2 の結果とほぼ一致している。一方, 試験 1 と試験 2 において，かいよう病に対する次亜塩素酸カル シウム製剂の希釈有効倍率に差が生じた。試験 1 は10 11月，試験 2 は $1 \sim 2$ 月に実施しており，かいよう病の 病勢進展は前者の方が早かったことから, 時期による病 原菌の感染力の違い等が影響した可能性が考えられる。

試験 3 に打ける各保管場所の照度，紫外線，気温を第 3 表に示す。本条件のもとで，次亜塩素酸カルシウム製 剂の500倍希釈液中の残留塩素濃度は，ビニールハウス 内で光遮蔽しない場合にのみ日数の経過とともに顕著に 低下した。調整時の塩素濃度は $1,458 \mathrm{ppm}$ であったが, 調整翌日には $1,078 \mathrm{ppm} ， 3$ 日後に $720 \mathrm{ppm} ， 5$ 日後に $286 \mathrm{ppm}, 7$ 日後には $118 \mathrm{ppm}$ に低下した。一方, 光遮 蔽をした場合や室内では保存場所に関係なく調整 7 日後 まで残留塩素濃度は低下しなかった（第 1 図）。次亜塩 素酸カルシウム溶液中の残留塩素濃度は, 光遮断をしな いと八ウス内では顕著に低下することから，作業時には 消毒液を入れた容器を光遮蔽するとともに，溶液はこま めに交換した方が良いと考元られる。一方，希积溶液中 の残留塩素濃度は, 光遮蔽して保管することにより, 少
なくとも 1 週間程度は低下しなかった。次亜塩素酸カル シウム製剂は，水にやや溶けにくいため，使用する数日 前にまとめて調整し，暗所で保存することも可能である と考元られた。

以上の結果, 次亜塩素酸カルシウム製剤の希釈有効倍 率は, トマト青枯病とかいよう病で異なることが示唆さ

第 1 表 次亜塩素酸カルシウム製剤の希釈倍率と青枯病, かい よう病の二次伝染抑制効果

\begin{tabular}{rrrc}
\hline \multirow{2}{*}{ 希釈倍率 } & $\begin{array}{c}\text { 有効塩素濃度 } \\
(\mathrm{ppm})\end{array}$ & \multicolumn{2}{c}{ 発病株率 $(\%)$} \\
\cline { 3 - 4 } & & 青枯病 & かいよう病 \\
\hline 水 (対照) & 0 & 100 & 100 \\
$\times 512,000$ & 1 & 100 & 100 \\
$\times 256,000$ & 3 & 100 & 100 \\
$\times 128,000$ & 5 & 100 & 100 \\
$\times 64,000$ & 11 & 100 & 100 \\
$\times 32,000$ & 22 & 100 & 100 \\
$\times 16,000$ & 44 & 75 & 100 \\
$\times 8,000$ & 88 & 63 & 100 \\
$\times 4,000$ & 175 & 25 & 100 \\
$\times 2,000$ & 350 & 0 & 75 \\
$\times 1,000$ & 700 & 0 & 25 \\
$\times 500$ & 1,400 & 0 & 25 \\
\hline
\end{tabular}

注）2015.10.20-11.19, 有効塩素濃度は成分量からの計算值, 各区 8 株供試，処理30日後調査。

第 2 表 次亜塩素酸カルシウム製剤の希勫倍率とかいよう病の 発病推移

\begin{tabular}{crrrrr}
\hline \multirow{2}{*}{ 希釈倍率 } & $\begin{array}{c}\text { 有効塩素濃度 } \\
(\mathrm{ppm})\end{array}$ & \multicolumn{4}{c}{ 発病株率 $(\%)$} \\
\cline { 3 - 6 } & & 15日後 & 20日後 & 30日後 & 35 日後 \\
\hline 水 (対照) & 0 & 75 & 100 & 100 & 100 \\
$\times 8,000$ & 88 & 8 & 33 & 67 & 67 \\
$\times 4,000$ & 175 & 0 & 8 & 42 & 42 \\
$\times 2,000$ & 350 & 0 & 0 & 25 & 33 \\
$\times 1,000$ & 700 & 0 & 0 & 8 & 8 \\
$\times 500$ & 1,400 & 0 & 0 & 0 & 0 \\
$\times 100$ & 7,000 & 0 & 0 & 0 & 0 \\
$\times 10$ & 70,000 & 0 & 0 & 0 & 0 \\
\hline
\end{tabular}

注）2016.1.13-2.17，各区12株供試，処理35日後調査。

第 3 表 試験期間中の照度，紫外線，気温の推移

\begin{tabular}{|c|c|c|c|c|c|c|c|}
\hline & \multicolumn{2}{|c|}{ 照度（1x） } & \multicolumn{2}{|c|}{ 紫外線（mW/cm²） } & \multicolumn{3}{|c|}{ 気温 $\left({ }^{\circ} \mathrm{C}\right)$} \\
\hline & $\begin{array}{l}\text { ビニール } \\
\text { ハウス }\end{array}$ & 室内 & $\begin{array}{c}\text { ビニール } \\
\text { ハウス }\end{array}$ & 室内 & $\begin{array}{c}\text { ビニール } \\
\text { ハウス }\end{array}$ & 室内 & 冷蔵庫 \\
\hline 平均 & 3,869 & 38 & 0.06 & 0.00 & 17 & 20 & 5 \\
\hline 最高 & 39,460 & 271 & 0.47 & 0.00 & 33 & 21 & 8 \\
\hline 最低 & 0 & 0 & 0.00 & 0.00 & 9 & 19 & 5 \\
\hline
\end{tabular}

注） 2015.11.13-20 


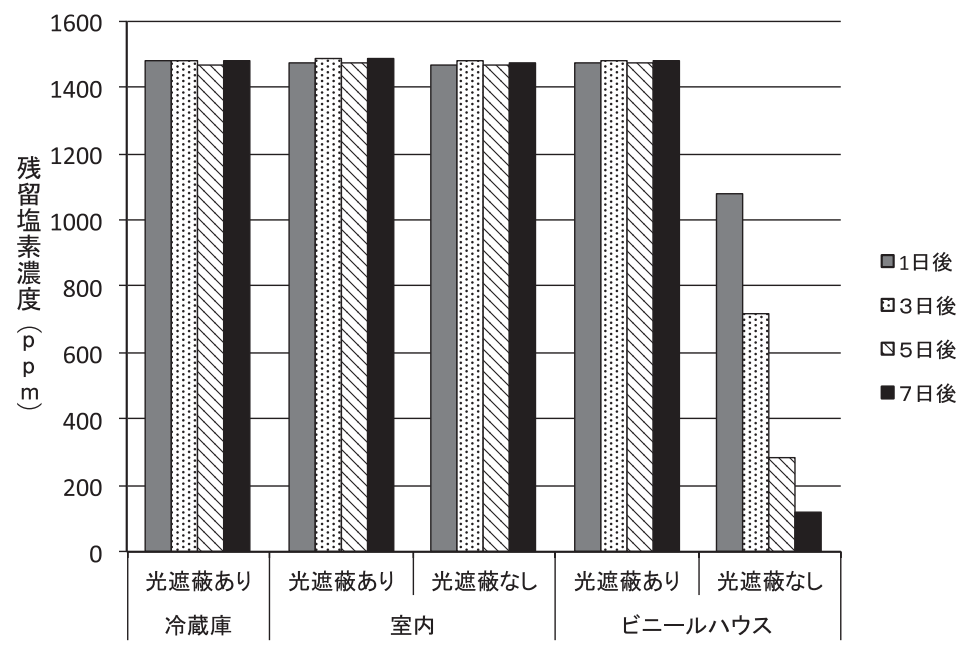

第 1 図 次亜塩素酸カルシウム溶液（500倍希釈）の保存方法が残留塩素濃度に及ぼす影響

れたが，500倍以下であれば両病害ともに抑制できると 考えられる。青枯病やかいよう病の発病適期である夏季 には, 光や温度等によって有効塩素の分解が早く進むこ とが予想されるため, 次亜塩素酸カルシウム製剤は 100 倍程度で使用することが望ましいと考える。また，調整 後の溶液は有効塩素濃度を保つため, 容器の遮光や保管 方法に注意すべきである。

\section{引用文献}

川口＼cjkstart章・谷名光治・井上幸次（2011）近畿四国中国農研 $18: 13-17$.

漆原寿彦・原 昌生・小林修武・酒井 宏・白石俊昌（2002） 関東病虫研報 $49: 39-41$. 